\title{
Noise-Induced Hearing Loss (NIHL): literature review with a focus on occupational medicine
}

\author{
Mirella Melo Metidieri', Hugo Fernandes Santos Rodrigues', Francisco José Motta Barros de Oliveira Filho ', \\ Daniela Pereira Ferraz', Antonio Fausto de Almeida Neto', Sandro Torres².
}

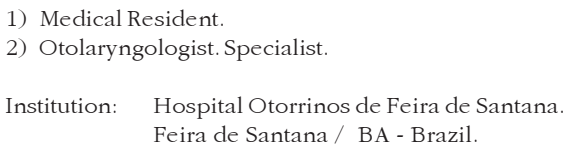

\section{SUMMARY}

According to the Ministry of Health (2006), Noise-Induced Hearing Loss (NIHL) is hearing loss caused by prolonged exposure to noise. It is characterized as sensorineural hearing loss and is usually bilateral, irreversible, and progressive while the exposure to noise continues. A NIHL is a predictable and preventable disease with an epidemiologically relevant prevalence in urban communities. The hearing loss begins and predominates in the frequencies of 3, 4, and $6 \mathrm{kHz}$ and eventually progresses to $8,2,1,0.5$, and $0.25 \mathrm{kHz}$. In Brazil, regulatory standard 15 limits the exposure to continuous noise to no more than 4 hours' exposure to $90 \mathrm{dBA}$ and a maximum level of $85 \mathrm{~dB}$ for a full 8-hour working period. As NIHL is a preventable and predictable disease, preventive action by professionals may be able to change the prevalence of hearing loss in noisy environments.

Keywords: hearing loss; hearing loss, noise-induced; noise, occupational.

\section{INTRODUCTION}

The Department of Health of Brazil (2006) defines Noise-Induced Hearing Loss (NIHL) as hearing loss caused by prolonged exposure to noise. It is characterized as sensorineural hearing loss and is usually bilateral, irreversible, and progressive while the exposure to noise continues.

NIHL is a predictable and preventable disease with an epidemiologically relevant prevalence in urban communities. It is also called hearing loss from exposure to noise at work, occupational hearing loss, or professional deafness. It begins and prevails at frequencies of 3, 4, and $6 \mathrm{kHz}$, progressing later to frequencies of $8,2,1,0.5$, and $0.25 \mathrm{kHz}$.

However, when we study occupational hearing loss, we should remember that noise exposure can coexist with other causal agents that may interact with the noise and enhance its effects on hearing. These include exposure to certain chemicals, vibrations, the use of some medications, and individual susceptibility.

Morata and Lemasters (1995 apud Department of
Health, 2006) proposed the use of the term "occupational hearing loss" because it is more inclusive, comprising the noise, which is undoubtedly the most frequently responsible agent, but also other causes, all of which should be considered in the implementation of diagnostic and preventive measures, limits, and safety legislation.

The U.S. safety standards commissioned by the Occupational Safety and Health Administration (OSHA) permit unprotected exposure to noise up to $90 \mathrm{dBA}$ for up to 8 hours with annual monitoring. In Brazil, the regulation 15 of the consolidated labor laws (NR-15) limits the exposure to continuous noise at $90 \mathrm{dBA}$ to a period of 4 hours and the decibel level to $85 \mathrm{~dB}$ for a full 8-hour work day.

Hearing loss caused by continuous exposure to noise can cause several functional limitations of hearing, i.e., changes in frequency selectivity, temporal and spatial resolution, recruitment, and tinnitus as well as changes in hearing sensitivity (Samelli, 2004).

\section{Materials ANd Methods}

This analysis consisted of a literature review, which 
encompassed only data from published sources. The database of international literature reviewed included all materials produced by the National Library of Medicine (NLM) and stored in MEDLINE. Other virtual libraries used included the selected collection of Brazilian scientific journals based on Fapesp and hosted and stored in SciELO.

\section{DISCUSSION AND LITERATURE REVIEW}

In 1996, the National Institute for Occupational Safety and Health (NIOSH), an agency of the government of the United States of America, published a practical guide for Occupational Hearing Loss Prevention using the term "occupational hearing loss," which encompasses not only hearing loss caused by exposure to aromatic solvents, metals, and some asphyxiating agents or to vibration, thus encouraging research into these and other factors that could potentiate hearing loss, but also noise-induced hearing loss (Fiorini; Nascimento, 2001).

It is estimated that $25 \%$ of the working population is exposed to a level of nose that will lead to some degree of NIHL (Bergstrom; Nystrom, 1986; Carnicelli, 1988; Morata, 1990; Prospero, 1999). Although NIHL is the most common work-related injury, its prevalence in Brazil remains poorly understood. This reinforces the importance of reporting, which enables accurate assessment of the situation and appropriate scaling of the necessary prevention and assistance measures.

The most striking feature of NIHL is the degeneration of the ciliated cells of the organ of Corti. Recently, these lesions and the onset of cellular apoptosis have been demonstrated to stem from oxidation caused by the presence of free radicals formed by the excessive sound stimulation or by exposure to certain chemicals. These findings have led to the study of substances and conditions that can protect cochlear ciliated cells against the insults of noise and chemicals (Oliveira, 2001, 2002; Hyppolito, 2003).

According to the Department of Health in 1998, the National Committee on Noise and Hearing Conservation defined the characteristics of Pair as follows:

- Always sensorineural, once the organ of Corti in the inner ear has been damaged.

- Usually bilateral, with similar patterns in each ear. In some situations, the degree of hearing loss differs between the ears.

- Usually does not produce hearing loss greater than $40 \mathrm{~dB}(\mathrm{NA})$ at low frequencies and $75 \mathrm{~dB}(\mathrm{NA})$ at high frequencies.
- The progression ceases when the exposure to intense noise ends.

- The presence of NIHL does not make the ear more sensitive to noise; as the threshold increases, the progression of the loss slows.

- The hearing loss begins and predominates in the frequencies of 3,4 , and $6 \mathrm{kHz}$ and eventually progresses to $8,2,1,0.5$, and $0.25 \mathrm{kHz}$.

- With stable exposure conditions, the losses in 3, 4, and $6 \mathrm{kHz}$ range generally plateau after about 10 to 15 years.

- The worker with NIHL may develop intolerance to loud sounds and complain of tinnitus and reduced speech intelligibility, which hampers oral communication.

Changes in frequency selectivity also cause difficulties in auditory discrimination. This injury increases the minimum time required to solve a sound event (temporal resolution), which, especially in association with the reverberation of the work environment, limits the ability of the patient with NIHL to recognize sounds (Bamford; Saundes, 1991). The worker with NIHL may develop intolerance to loud sounds and complain of tinnitus, reduced speech intelligibility, and impaired verbal communication. In a study of 3466 workers who applied for compensation because of NIHL, McShane, Hyde, and Alberti (1988) reported a 49.8\% prevalence of tinnitus. Of the affected subjects, 29.2\% stated that tinnitus was their main problem.

The diagnosis of NIHL is based on clinical and occupational research in which the prior and current exposure to risk is evaluated and the characteristic symptoms described earlier (Department of Health, 2006) are considered. The diagnostic work-up should also include audiometry evaluation.

It is important to detail the exposure to allow correlation between the exposure and the signs and symptoms of NIHL. Occupational anamnesis is thus an essential tool for risk identification. Such knowledge about the working environment can be obtained through site visits, review of the company's technical reports, and information from inspections as well as from the patient's report.

It is essential to confirm the presence of hearing loss by an audiological evaluation. This consists of the following tests: pure tone audiometry by air conduction (despite its subjective nature), pure tone audiometry by bone conduction; speech audiometry, and immittance. To be reliable, this assessment must be performed under the conditions established by Ordinance No. 19 of the Regulatory Norm no. 7 (NR-7). 
The diagnostic work-up should be performed in a way that minimizes the influence of confounding factors extrinsic to the examination, and it is therefore important to use a soundproof booth and calibrated equipment, to have the exam performed by a qualified professional (doctor or audiologist), and to instruct the patient to perform sound rest for 14 hours before the exam. The examiner must also consider potentially confounding factors intrinsic to the examination, i.e., those related to the patient and his or her general condition, motivation, intelligence, attention, familiarity with the task, and interpretation of the test instructions.

When prior hearing assessments exist, they should be compared with the current assessment to determine whether there has been progressive hearing loss, which in NIHL begins and predominates in the frequencies of 3,4 , and $6 \mathrm{kHz}$ and later progresses to 8, 2, 1, 0.5, and $0.25 \mathrm{kHz}$. Likewise, it should be considered that with stable exposure to noise, the losses in the 3,4 , and $6 \mathrm{kHz}$ range generally plateau within approximately 10 to 15 years.

It is important to differentiate NIHL from other auditory pathologies that have different characteristics despite having the same etiology and, possibly, occurring in association with the work environment. Thus, we should remember that "the effects of noise can cause: acoustic trauma, temporary change in hearing threshold and hearing loss" (Maia, 2006).

There is as yet no treatment for NIHL. The key is to limit the damage by notifying the appropriate individuals to initiate health surveillance and then monitor the progression of hearing loss through periodic audiological evaluations. Even now, careful analysis of the worker's audiological evaluation can lead to rehabilitation through individual actions and group therapies.

As noise is an occupational hazard, prevention efforts must be implemented in the work environment. As described earlier, there is legislation defining exposure limits as well as guidance on programs to prevent and control risks. Companies must follow these guidelines in accordance with the Regulatory Standards of the Ministry of Labor: A Prevention Program Environmental Risks (PPRA-NR-9), which state that the various risks in the workplace must be identified, quantified, and reported to the Medical Control of Occupational Health (PCMSONR7), which will use the information to determine and proceed with the appropriate assessments of the workers' health.

The actions taken to control NIHL are related to noise control. Measures should be taken to control the exposure at the source, trajectory, and individual levels. In addition, organizational measures, such as reducing travel, establishing breaks, and rotating shifts through the noisy area, can be effective.

Noise is defined as a "physical agent capable of causing damage to the human body with the short and medium term effects" (Paraguay, 1999). The word is usually associated with an unpleasant sound with chaotic and irregular frequencies. Noise produced in public spaces in such excess that it contributes to an undesirable environment is called noise pollution. Such pollution, which can be intolerable, is becoming one of the environmental problems affecting the greatest number of people according to the WHO (WORLD HEALTH ORGANIZATION, 2009).

As the sensitivity of the human ear is highest in the frequency range of 2,000 $\mathrm{Hz}$ to $4,000 \mathrm{~Hz}$, Regulatory Norm number 15 (NR-15), through the Decree no 3.214/ 1978 (BRAZIL, 1978), establishes limits for exposure to continuous noise in this range, as shown in Table 1 below.

According to Miranda et al., the prevalence of hearing loss among workers in the metropolitan region of Salvador was $45.9 \%$ in the population studied. The

Table I. Noise NR-I5.

\begin{tabular}{cl}
\hline Noise $(\mathrm{DB})(\mathrm{A})$ & Maximumallowable daily exposure \\
\hline 85 & 8 hours \\
86 & 7 hours \\
87 & 6 hours \\
88 & 5 hours \\
89 & 4 hours and 30 minutes \\
90 & 4 hours \\
91 & 3 hours and 30 minutes \\
92 & 3 hours \\
93 & 2 hours and 40 minutes \\
94 & 2 hours and 15 minutes \\
95 & 2 hours \\
96 & 1 hourand 45 minutes \\
98 & 1 hourand 15 minutes \\
100 & 1 hour \\
102 & 45 minutes \\
104 & 35 minutes \\
106 & 30 minutes \\
108 & 20 minutes \\
110 & 15 minutes \\
112 & 10 minutes \\
114 & 8 minutes \\
115 & 7 minutes \\
\hline 19 &
\end{tabular}

Source: http://www.areaseg.com/acustica/ 
prevalence of hearing loss induced by noise (PAIR), including bilateral and unilateral losses, was $35.7 \%$. When such hearing loss was broken down by occupation, the individual prevalence rates were: $58.7 \%$ in publishing/ graphic, $51.7 \%$ in mechanical, $45.9 \%$ in beverage-related, $42.3 \%$ in chemical/petrochemical, $35.8 \%$ in metallurgic, $33.5 \%$ in steel, $29.3 \%$ in transport, $28.0 \%$ in food, and $23.4 \%$ in textile industry. The prevalence of unilateral NIHL was notably high in this study at $18 \%$ of workers evaluated. The magnitude of the prevalence of hearing loss induced by noise reported in this study represents an extremely alarming situation and points to the importance of the implementation of Hearing Conservation Programs by employers in order to prevent this disease.

\section{CONCLUSION}

Work-related hearing loss, particularly NIHL, is a highly prevalent occupational disease and a prominent occupational health hazard.

We can also conclude that exposure to high sound pressure levels can cause irreversible hearing loss, which has serious consequences for individuals' health and quality of life. Therefore, NIHL warrants increased concern and efforts to take such steps as are within the individual's control to make the work environment suitable for human occupation.

As NIHL is a preventable and predictable disease, preventive actions by professionals may be able to change the incidence of hearing loss in noisy environments. Therefore, occupational health professionals must emphasize the importance of corporate Hearing Conservation Programs and audiometric management of workers.

\section{REFERENCES}

Bamford J, Saunders E. Hearing impairment, auditory perception and language disability. 2ed. San Diego, California: Singular Publishing Group, 1991.

Bergström B, Nyström B. Development of hearing loss during long term exposure to occupational noise. Scand Audiol. $1986 ; 15(4): 227-34$.

Brito VPS. Incidência de Perda Auditiva Induzida por Ruído em Trabalhadores de uma Fábrica [thesis]. [Goiania]: CEFAC: Centro de Especialização em Fonoaudiologia Clínica; 1999. trabalhador: organização e desenvolvimento de um programa audiológico numa indústria têxtil da cidade de SãoPaulo[thesis]. [SãoPaulo]:Pontifícia UniversidadeCatólica; 1988.

Fiorini AC, Nascimento PES. Programa de Prevenção de Perdas Auditivas. In: Nudelmann AA, et al. Pair - Perda Auditiva Induzida pelo Ruído: volume II. Rio de Janeiro: Revinter; 2001.

Hyppolito MA, et al. Ototoxicidade da cisplatina e otoproteção pelo extrato de ginkgo biloba às células ciliadas externas: estudo anatômico e eletrofisiológico. Rev. Bras. Otorrinolaringol. 2003;69(4):504-11.

Maia JRF. Estudo da audição de músicos de Rock and Roll. [thesis]. [São Paulo]: PUC; 2006.

Merluzzi F. Patologia da rumore. In: Sartorelli E. Trattato di medicina del lavoro. Vol. 2. Pádua: Piccin Editore; 1981. p. 1119-1149.

MINISTÉRIODA SAÚDE. Perda Auditiva Induzida por Ruído. Brasília-DF: Editora MS; 2006.

Miranda CR, Dias CR, Pena PGL, et al. Perda auditiva induzida pelo ruído em trabalhadores industriais da região metropolitana de Salvador, Bahia. Inf. Epidemiol. Sus, mar. 1998;7(1):87-94.

Morata TC. An epidemiological study of the effects of exposure to noise and organic solvents on workers hearing and balance[dissertation]. [Cincinnati]: University of Cincinnati; 1990.

Oliveira JAA. Prevenção e proteção contra perda auditiva induzida pelo ruído. In: Nudelmann AA, et al. Pair - Perda Auditiva Induzida pelo Ruído: volume II. Rio de Janeiro: Revinter; 2001.

OMS-ORGANIZAÇÃO MUNDIAL DA SAÚDE. WHO- Night noise guidelines for Europe [Internet]. Genève: World Health Organization; 2009. [cited 2012 Sep 30]. Available from: http://www.euro.who.int/_data/assets/pdf_file/0017/ 43316/E92845.pdf

Paraguay ATT. Perda Auditiva Induzida por Ruído em Consultório Odontológico [thesis]. [Recife]: Curso de Especialização em Fonoaudiologia Clínica; 1999.

Pereira CA. Surdez Profissional: caracterização e encaminhamento. Rev. Brasileira de Saúde Pública. 1989;65(17):43-5.

Próspero AC. Estudo dos efeitos do ruído em servidores do 
Centro Técnico Aeroespacial [thesis]. [São Paulo]: Pontifícia Universidade Católica; 1999.

Samelli AG. Zumbido: avaliação, diagnóstico e reabilitação: abordagens atuais. São Paulo: Lovise; 2004.
Santos UP, Morata TC. Efeitos do ruído na audição. In: Santos UP, editor. Ruído: riscos e prevenção. São Paulo: HUCITEC; 1994. p. 7-23. 